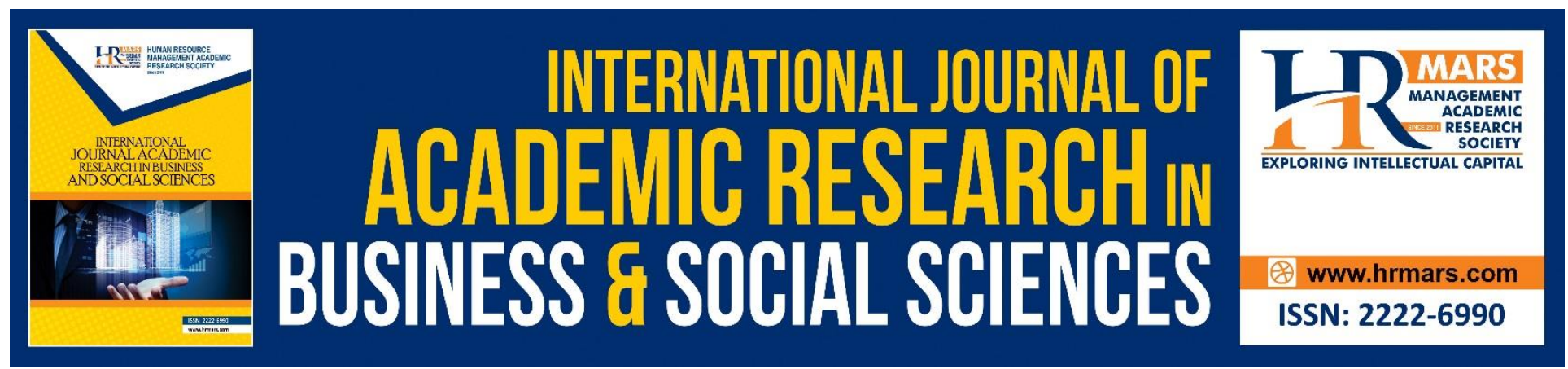

\title{
Human Resource Management Practices and Organizational Commitment: Research Methods, Issues, and Future Directions
}

\author{
Hamid Masud, Wan Norhayate Wan Daud, Fakhrul Anwar Zainol, \\ Norfadzilah Rashid, Asyraf Afthanorhan
}

To Link this Article: http://dx.doi.org/10.6007/IJARBSS/v8-i11/5159

DOI: $10.6007 /$ IJARBSS/v8-i11/5159

Received: 03 Oct 2018, Revised: 12 Nov 2018, Accepted: 26 Nov 2018

Published Online: 29 Nov 2018

In-Text Citation: (Masud, Daud, Zainol, Rashid, \& Afthanorhan, 2018)

To Cite this Article: Masud, H., Daud, W. N. W., Zainol, F. A., Rashid, N., \& Afthanorhan, A. (2018). Human Resource Management Practices and Organizational Commitment: Research Methods, Issues, and Future Directions. International Journal of Academic Research in Business and Social Sciences, 8(11), 1134-1148.

Copyright: (C) 2018 The Author(s)

Published by Human Resource Management Academic Research Society (www.hrmars.com)

This article is published under the Creative Commons Attribution (CC BY 4.0) license. Anyone may reproduce, distribute, translate and create derivative works of this article (for both commercial and non-commercial purposes), subject to full attribution to the original publication and authors. The full terms of this license may be seen at: http://creativecommons.org/licences/by/4.0/legalcode

Vol. 8, No. 11, 2018, Pg. 1134 - 1148

http://hrmars.com/index.php/pages/detail/IJARBSS JOURNAL HOMEPAGE

Full Terms \& Conditions of access and use can be found at http://hrmars.com/index.php/pages/detail/publication-ethics 


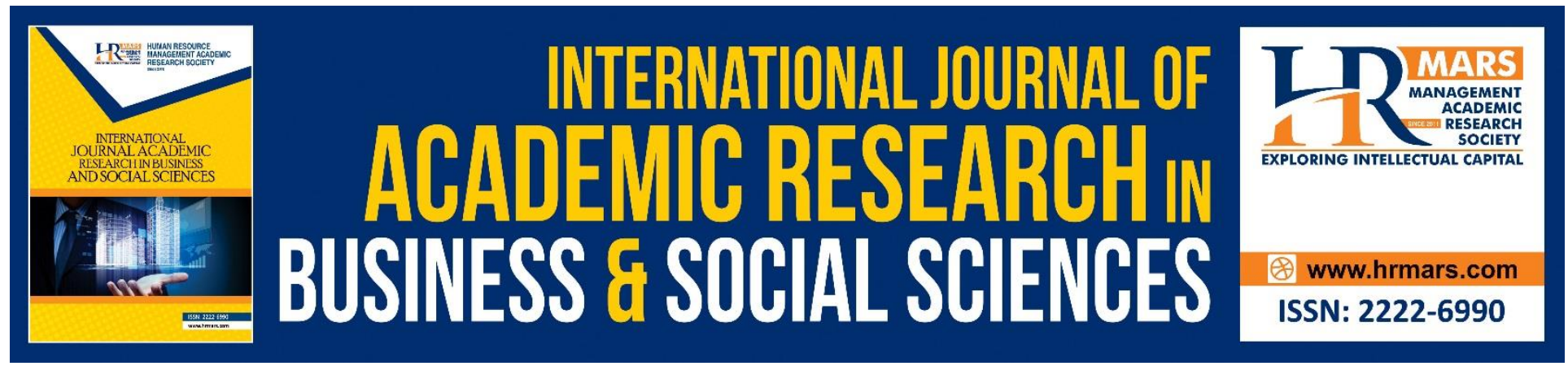

\title{
Human Resource Management Practices and Organizational Commitment: Research Methods, Issues, and Future Directions
}

\author{
${ }^{1}$ Hamid Masud, ${ }^{2}$ Wan Norhayate Wan Daud, ${ }^{3}$ Fakhrul Anwar \\ Zainol, ${ }^{4}$ Norfadzilah Rashid, ${ }^{5}$ Asyraf Afthanorhan \\ ${ }^{1}$ COMSATS University (Virtual Campus), Islamabad, Pakistan \\ 2,3,4,5 Faculty of Economics and Management Sciences, Universiti Sultan Zainal Abidin, 21300 \\ Kuala Nerus, Terengganu, Malaysia \\ Corresponding Author: wnhayate@unisza.edu.my
}

\begin{abstract}
A paper aims to analyze the different methodologies adopted by HR scholars by examining the relationship between HRM practices and organizational commitment (OC). Previous studies, which published in 2001-2016 with a total of 63 studies selected for this review. A report shows that the majority of the scholars adopted Surveys at individual and multi-level. However, lately, many scholars also started adopting mix-method, and this trend is growing with the passage of time, and it brought some essential contributions in HR and OC research. Now, HR-OC is not limited to individual level research. Scholars have now broadened their vision and started adopting research on multi-level and cross-sectional level research designs. An effort has been made for a brief explanation of new methods so that future researchers could overcome the deficiencies and contribute significantly in commitment of their research.
\end{abstract}

Keywords: Organizational commitment, Human resource management, HRM practices, Turnover Introduction

Over last few decades, research on Human resource has gained the much importance in organizational settings. After WWII it helped industries, local and international, to adopt and develop outside/inside approach (meeting stakeholder's expectations) for sustainable growth. HR function gained much fame after WWII due to lack of proper infrastructure for organizational 
development. At that time, HR was only responsible for management of internal functions. They strategized essential steps to bring all stakeholders closer to gain favorable work-outcomes. With the passage of time, HR scholars found that commitment of employees is significant to maintain a healthy environment and for the smooth functioning of organizational activities. Though similar constructs, like job embeddedness, it introduced by scholars in a situation where the commitment of employees gained much fame as it is directly linked with different employee attitudes like satisfaction, turnover and citizenship behavior (cf. Klein, Becker, \& Meyer, 2009). $H R$ research has brought forward beneficial insights into literature. The reason is that $H R$ practices have a direct association with the commitment of employees (Ramaprasad et al., 2017). In the absence of such methods, organizations face a high rate of turnover which is not suitable for smooth functioning and results in wastage of financial and social resources. Contrary to it, adoption of useful practices and methods not only helps in retaining employees but also leads towards building a positive image in the market. Based on the past research, HR-OC research brings forward essential implications for practitioners and HR scholars which helped which lead towards effective organizational development (Hayton et al., 2011). As a result of the healthy relationship between HR practices and commitment of employees, all stakeholders can get the desired outcomes. That's why it was needed to examine the role of HR practices and their impacts on the commitment of employees.

Theoretical and empirical contributions in past literature helped future scholars to think differently. Prior studies contributed to human resource literature by pointing out various essential developments which proved to be a sound basis for future empirical research (Wall \& Wood, 2005). It is important to note that the implementation of HR practices at the right time and right place is equally important to get desired outcomes, especially the commitment of employees. That's why it was a needed to integrate past studies (relevant to HR-OC relationship) to move forward for a better understanding of their relationship.

Current review study is limited to the following domain:

\section{Research Question 1.}

Which methodologies have been used in past studies about HRM and OC which opened new gate-way for future research?

With the growing ratio of turnover, HR scholars started analyzing methodological developments in HR-commitment research and regarded this relationship as a psychological state (Meyer \& Herscovitch, 2001) which helps in getting favorable organizational outcomes by motivating employees and developing positive attitudes towards the accomplishment of organizational goals. Adding to this, it also helps in enhancing their positive attitude towards staying with their current employer (Mowday et al., 1979). Research shows that employees showing commitment towards their organizations have high morals, better individual performance, low turnover rate and reduced absenteeism (e.g., Riketta, 2002; Wasti, 2003). High commitment values among 
INTERNATIONAL JOURNAL OF ACADEMIC RESEARCH IN BUSINESS AND SOCIAL SCIENCES Vol. 8, No. 11, Nov, 2018, E-ISSN: 2222-6990 @ 2018 HRMARS

employees lead them towards intrinsic as well as extrinsic rewards like job satisfaction and recognition, rewards, and motivation (Mowday, 1983).

Secondly, current research regards Human resource and organizational commitment relationship as an antecedent-consequent profile. Meyer and Smith (2000) initiated this debate that HR practices have a significant relationship with the commitment of employees. Though several other antecedents, like organizational, job and personal characteristics, have been highlighted in past research (Meyer et al., (2002). To explain HRM-OC relationship, social exchange theory (Blau, 1964) came to the front and stated that to maintain the excellent relationship between organization and employees, organizations must arrange good practices which will build positive work behaviors between internal stakeholders. Adding to this, signaling theory (2000) explains that provision of such healthy practices for employees serves as a signal emitted by the firms towards their employee's welfare with the intention to facilitate them for their maximum satisfaction (Rousseau, 1995). In turn, the provision of such support and incentives will motivate the employees towards positive work behaviors and outcomes (Hannah \& Iverson, 2004).

Commitment research has revealed that it produces favorable outcomes for both employees and organizations and also it proved to be a useful criterion to examine HR practices and their effectiveness. These facts lead HR scholars to investigate HR-OC relationship for further elaboration of their relationship. Though there has been an increase in HRM-OC research (e.g., Ramaprasad et al., 2017) and also there are numerous reviews which analyzed their relationship, but there are very few studies which focused and synthesized the methodological advancement in HRM-OC relationship. This review will fill to this gap in the literature and will help an in-depth study for future researchers. Past literature highlighted validity issues which were prominent due to wrong or inadequate research designs and methods. That's why this review has more essential contributions to discuss which earlier studies failed to identify. Thus, a common perception that arises after the emergence of HR literature is that organizations and employees get benefits out of these policies and this has built confidence in the further investigation of HRM practices. Besides, HR scholars felt the adoption of suitable methodologies for the expansion of HRM literature and felt that HRM literature lacks adoption of suitable methodology which needs to be addressed (Huselid \& Becker, 2000). That's why strong need was felt to know that whether studies, which were published in the 20th century, focused on this issue and adopted modern methodologies to analyze HRM-OC relationship?

The objective of this paper is to sort out and integrate past literature (HRM-OC) to find out the methodology that was used in research studies published in 2001-2016. This review summarizes research design, sources of information, methodologies of data collection, analytical techniques and research approach applied in past studies for the period 2001-2016 for the said relationship. in addition, the current review also highlights methodological issues and also suggests solutions to overcome it. In the first part, the methodology of the current review will be discussed. The last 
section will discuss the key findings of the study. Research implications and future directions are given in the last section.

\section{Identification Relevant Studies}

Several databases, like Google Scholar, Taylor, and Francis, JSTOR, Science Direct, Springer link, were used to identify the relevant studies (HRM-OC). In the first phase, search terms "Human resource management practices and organizational commitment," Human resource management practices and commitment measures," HRM and commitment of employees," high environment work practices and "role of HRM in determining organizational commitment" were used for locating relevant studies. After finding studies, references to these studies were used for further search of relevant studies. In the next step, references of relevant studies were scrutinized and after finding relevant studies were included in this review. All unpublished or under-review work was not included in this review. As a result, only 36 studies were selected for this review.

\section{Inclusion criteria}

\section{Stage I: inclusion/exclusion criteria}

In the first stage, the authors decided upon inclusion/exclusion criteria for selecting relevant studies in the HRM-OC discourse. Other factors which were considered for selection of relevant studies include readership, publication year, variables and type of papers. Relevant studies, which were published in international peer-reviewed journals, were included in this review. Studies which were published before 2001 and after 2016 were not included in this review. Studies which discussed more than one practices of HRM and OC were included in this review. Studies, which reported only one HR practice was not included in this review. Findings of HR literature show that the application of HRM bundles posits more outcomes as compared to individuals practices (Hayton et al., 2011).

\section{Stage II: Selection, Data Collection, and Content Analysis}

Review of the study revealed that selected studies were published in famous international journals like Journal of Management Studies, Journal of Applied Psychology, Personnel Psychology, Employee Relations, Human Resource Management Journal and The International Journal of Human Resource Management.

In the next part, relevant studies were identified with the help of search terms.

Inclusion criteria for this review are termed as studies which were published between 2001 and 2016, which presented original data, published in English and focused on human resource management practices and organizational commitment. Studies, which used variables other than HRM practices were not included in this review. Meta-analysis, conceptual and qualitative studies, which were not published, were not considered part of this review. 
INTERNATIONAL JOURNAL OF ACADEMIC RESEARCH IN BUSINESS AND SOCIAL SCIENCES

Vol. 8, No. 11, Nov, 2018, E-ISSN: 2222-6990 @ 2018 HRMARS

\section{Data Analysis}

\section{Data Selection Process}

After the identification of relevant studies, particular information was tabulated. All studies were later on analyzed to find their suitability for the current review.

\section{Classification of Studies}

After a thorough review, careful studies were classified as included for review or excluded from the review. Overall 36 studies were selected which met all the inclusion criteria which were set for this study. All of these published studies were categorized and then coded.

\section{Screening}

Once studies were selected, in the next step, all relevant information was then extracted so that primary objective of the study could be elaborated properly. After excluding relevant information, data was arranged systematically to synthesize and to fill the gap. This whole process was done with much care to make a solid base for the study.

\section{Evident Findings}

Reasons for selecting this particular issue is that research findings show several favorable outcomes related to HRM practices. Organizations attain desired organizational outcomes once they start practicing HR practices. The authors undertook a systematic search and selection of relevant HRM-OC literature in three distinct stages.

\section{Findings}

\section{Research Approach}

It has been found that 48 studies adopted a quantitative methodology to analyze HRM-OC relationship (Fig. 5). The survey method was used to collect a response from the sample (Fig. 3). Typical methods for the survey in these studies were a web-based and postal method. Review analysis shows that the focus of past studies was either on qualitative or quantitative but currently most of the scholars prefer to adopt the mix-method approach (Fig. 1). 15 studies adopted mixed method approach while 14 studies used quantitative approach and followed interview method for studying HRM practices (e.g. Agarwala, 2003), to have deep understanding of HR practices at firm level (e.g. Kinnie et al., 2005), to better understand results based on quantitative findings (Gould-Williams, 2004), identifying unit of analysis (e.g. Chang and Chen, 2011) and building hypothesis (Boxall et al., 2011). In one study, Lai et al. (2016) used WERS database to collect responses from the required sample. A case-study approach was used by two authors (Boselie, 2010; Young et al., 2010). Young et al. (2010) used a mixed-method approach while Boselie (2010) adopted a survey method for collecting response and analyzing the data.

Studies were divided into individual, unit and multi-level analysis (Fig. 2). It was found that individual-level methodology was adopted by 43 studies while five studies adopted unit level and multi-level research design was adopted by 15 studies. Research findings show that researchers prefer to adopt individual-level research design. However, it has been observed that the ratio of using multi-level research design has also increased since the year 2008. 

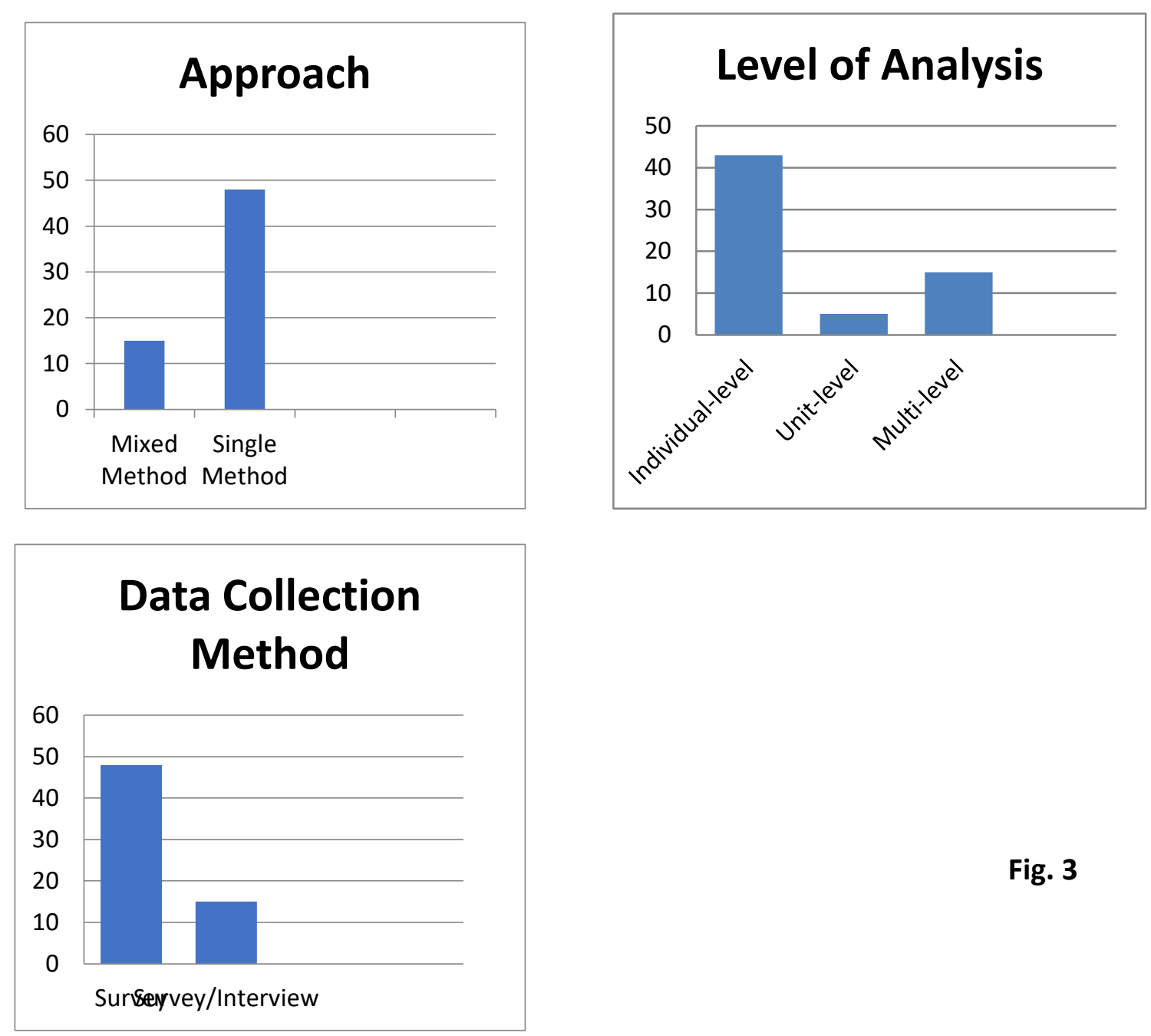

Fig. 3

\section{Source of Information}

Review analysis shows that single factor design has been adopted by $73 \%$ of studies. 46 studies got responses from the same source (i.e., from employees or managers). 17 studies take responses from different stakeholders. The multi-factor design was adopted by these studies adopted. For example, in one of the study Chang and Chen (2011) used a multi-level approach. Owner of salon shops reported a high-performance work system while their staff recorded their response for affective commitment. None of the studies adopted a single informant survey measurement strategy. Multiple instruments were used for collecting response. 


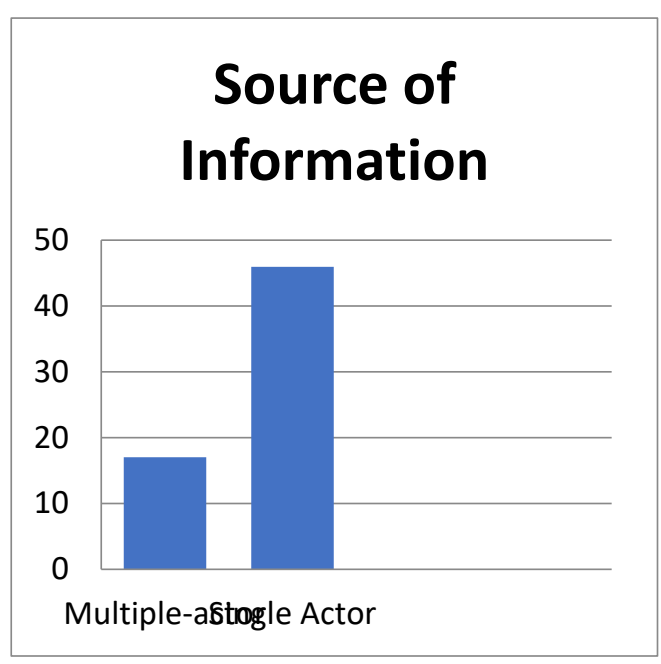

Fig. 5

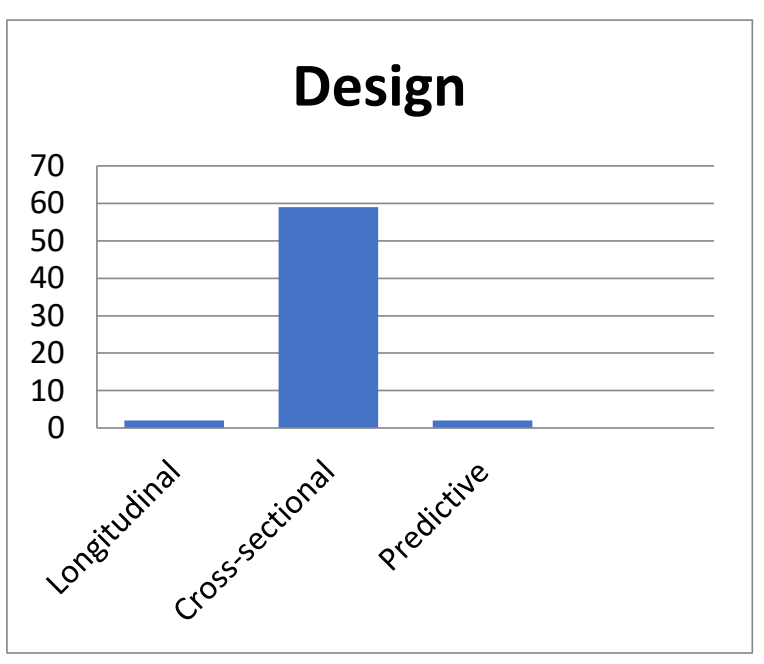

Fig. 4

\section{Research Design}

Review analysis shows that only two studies, (Gardner et al., 2011; Herrbach et al., 2009) adopted the longitudinal approach. It is important to note that different measures of organizational commitment were adopted by scholars. For example, Gardner et al. (2011) examined the relationship between $\mathrm{HR}$ practices and voluntary turnover with the help of affective commitment, while Herrbach et al. (2009) used organizational commitment as a whole variable to examine the relationship between HR practices and voluntary turnover. Most of the studies (59) adopted a cross-sectional design. Among these studies, only one study is found in which experimental and field study analysis technique was adopted by (Sanders and Yang, 2016).

\section{Discussions and Future Directions}

The study aims to provide with useful insight into usage of different methodologies which were applied in past studies (2001-2016) to examine the relationship of human resource management practices and organizational commitment. Upon analysis, it was found that most of the studies shown consistency with past research (e.g., Boselie et al., 2005; Paauwe, 2009) regarding the adoption of methodology. A single method, individual-level, and cross-sectional designs were the common methodologies which were applied in past studies.

Thought the contributions are very helpful and scholars, practitioners, and policymakers find it helpful to get desired outcomes, but there is an issue about the mechanism to examine the relationship between HRM practices and organizational commitment. It is therefore suggested that modern research methodologies like a longitudinal design, multi-level factor, and mixed method approach can be helpful to overcome this limitation.

\section{Research Methods}

\section{Mixed-Method Approach}

The current review reveals that $76 \%$ percent applied the single method to analyze the relationship between the said variables. Despite their in-depth understanding, studies which 
adopted quantitative methodology still lack to fully analyzing the phenomenon. According to Johnson and Christensen (2004), the subjective nature of qualitative studies also could not generate valuable results among these two variables (HRM-OC). So it became very difficult to generalize the results to the whole population. Both of the methodologies have their strengths and weaknesses. So it is better advised to mix of these approaches to get the collective strength of the relationship between these variables (Boselie et al., 2005).

So, the intense need of the mixed method approach is felt by the review of these studies. This fact has been recognized by majority of HR scholars, and they have started applying the mixedmethod approach in their studies since last decade. However, it is important to note that scholars have adopted this approach for the purpose of developing quantitative measures and they have done so with the help of qualitative information and interviews. There are vast opportunities for HR scholars to expand this research by applying a mixed-method approach and also to triangulate the results. For example, scholars can undergo a survey method to take the response from employees to get their views regarding the application of HRM practices. They also can conduct semi-structured interviews from managers for a better understanding of the HRM policies and practices followed by in-depth interviews to be taken from top management of the organization to get their viewpoint regarding their knowledge of HRM practices for their employees (e.g., Kinnie et al., 2005). It is to be noted that if the response is taken only from employees, the results cannot be generalized and do not represent the whole population. Also, the results can be misleading. This is because that application of a single-method approach would consider that all HRM practices are equally operationalized at a lower level as planned by top managers and is experienced same by all employees. Thus, the presence of mixed-method approach would help to give in-depth analysis of the variation which could exist between all three tiers of hierarchy and therefore it would help to explain the relationship in the detailed overview about planned, operationalized and experienced HRM practices. It would also help to triangulate the findings and analyze the results with other findings for the better understanding of the phenomenon (Johnson and Turner, 2003).

\section{Multi-level, Multi-Actor Approach}

This review highlights that individual-level analysis has been applied in $68 \%$ of the studies. It is to be noted that earlier studies related to HRM practices have used to adopt unit-level or organizational level studies (Gerhart, Wright, McMahan and Snell, 2000). Those studies could not contribute as effectively as the studies which applied mixed methods, but the findings of those preceding studies cannot be denied as they provide some useful insights into the relationship between the variables of interest (Wright et al., 2003). That's why need was felt to further elaborate the role of HRM practices in the presence of new mediators and moderators. Connecting this with the viewpoint of HRM scholars, when HRM practices are operationalized at macro-level, their output can be observed the organizational level in the form of favorable work outcomes only if individuals also face the effects of these HRM practices (at the micro level) (Bowen and Ostroff, 2004). It can be said that studies which have applied the micro level approach in their studies to examine HRM-OC relationship have most probably adopted this 
technique from this finding. However, it can be seen that organizations have involved levels of networking in their structure (Hitt et al., 2007).

It is important to note that organizations operate with multiple units (Hitt et al., 2007). It can be said that different characteristics or dimensions of organizational performance, employee attitudes, and HRM practices are developed and operationalized at different levels. Therefore care must be taken in adopting the right research design for the right sample as there exists variance in results at different levels of hierarchy (Wright \& Boswell, 2002). In this regard, a multilevel approach is more helpful as it does not involve any methodological issues (Arregle et al., 2006) which usually arise when single level (unit level) analysis is applied (Peterson et al., 2012). It is evident from this review that most of the studies have adopted a multi-level approach to analyzing the relationship between HRM-OC variables. For example, Chang and Chen (2011) analyzed both macro and micro level investigation by surveying high-performance work system information from important management (macro-level) which perceptions of affective commitment at the micro level. That's how they were able to provide keen insight into the relationship between variables especially the role of engagement in predicting favorable work outcomes. They found that effective commitment played the role of mediator between highperformance work system and employee performance.

The review shows that researchers have used both single actor and multi-actor approaches in the studies. A single-actor approach is the one in which response or information is collected only from the single category (employees or managers) while multi-actor designs collect information from different categories, like employees and managers on HR and outcome variables (Sanders et al., 2012). HR literature shows that earlier researcher used to adopt only a single-factor approach (e.g., Huselid \& Becker, 2000). This approach is a bit problematic as it does not deal with the issues of measurement errors and reliabilities. Hence, scholars suggest to increase the number of population sizes or to adopt a multi-actor approach (Gerhart, Wright \& McMahan, 2000). The review shows that most of the studies, around $73 \%$ studies adopted a single actor approach in examining the relationship of HRM-OC. As compared to unique actor design, multiple actor approaches are more accurate in dealing with the issues of validity and reliability. The reason is that it allows researchers to take the view of several stakeholders who in turn reduce such matters (Gerhart, Wright \& McMahan, 2000).

Despite several benefits attached to multi-actor approach, there is a serious issue with its usage, which is common method variance. This issue can be addressed if multiple stakeholders are involved in the analysis (Podsakoff et al., 2003). For example, in a study Chang (2005) examined the relationship between HRM practices and organizational commitment. Data was collected from different levels of employees, e.g. from managers and employees as well. So, future scholars must consider this factor in their studies that which aspect of HR they are going to analyze and who are the stakeholders of research. Adding to this, Arthur and Boyles (2007) suggests that if scholars want to know information about intended HRM practices, then their target should be top management of the organization, in case of implementation of HRM practices, scholars should consult line managers while if information regarding the experience of employees is required, then data can be gathered from individual employees. Huselid and Becker (2000) stated that scholars must pay serious attention towards knowledge of respondents. The 
reason is that if respondents don't have any knowledge regarding your subject matter, then there are equal chances that it will lead towards the issue of non-reliability. Therefore, future scholars are suggested to use the multi-actor approach in their studies to avoid all the related problems discussed above.

\section{Longitudinal Design}

The review shows that $94 \%$ studies adopted cross-section approach in examining the relationship between HRM practices and organizational commitment. Though cross-sectional design provides a possible causal relationship between variables, longitudinal study is best to practice as it allows the researcher to collect data at multiple times which can give more accurate data (Guest, 2011). Current review shows that only two studies (Gardner et al., 2011; Herrbach et al., 2009) adopted a longitudinal research design. They collected the data at period 1 and collected second response at time two they provided more accurate results as compared to the rest of studies.

The review shows that though there are several studies which examined HRM-OC relationship stating that HRM practices can result in different commitment measures which in turn results out into favorable work outcomes. But there might have a complicated situation when the reverse order of the HRM-OC relationship would be examined. This may be so because organizations can discriminate by giving good HR practices only to those employees who are more committed than the ones who are less committed. It is also likely that employees who are more committed are getting more HR practices and benefits and they may perceive it more favorable than the ones who are less committed, and due to this, organizations pay less attention towards them and implementing fewer HR practices for them (Kooij et al., 2010). Longitudinal design can be helpful to overcome this issue.

Another factor that must be kept in mind is the time-variant nature of organizational commitment. It has been found that commitment of employee's changes with the passage of time (Gao-Urhahn et al., 2016). The review shows that this fact has been neglected in most of the studies. Thus, collecting data only at one time may lead to biased results. It is therefore suggested that future scholars try to take responses at different spans of time to avoid such issues (Meyer and Allen, 1997).

It can be concluded that there is more need to conduct longitudinal studies to fill this gap and to overcome the issue of a time-variant factor in HRM-OC research. Most of the scholars avoid longitudinal design. Reasons may be that the several problems and issues related to this longitudinal research design like the presence of time-variance factors, missing data unwillingness of respondents to give feedback again, the time lag between two assessments and complex research design. Though these issues are concerned with this research design, this approach is more helpful in extracting good results as compared to the cross-sectional research

design (Little et al., 2009). Therefore, future scholars are advised to conduct longitudinal research on $\mathrm{HRM}-\mathrm{OC}$ relationship.

\section{Conclusion}

The objective of this review is to highlight and summarize different methodologies and research designs which have been used to examine the relationship between HRM-OC relationships (from 
single to multi-level, from a single method to mixed method). It is found that HRM-OC research is moving towards advanced levels. Scholars are now focusing towards changing methodological trends and improving research techniques by adopting multi-actor, multi-level or mixed methods approaches. Despite all advantages, longitudinal, multi-actor, multi-level or mixed method approaches are still very short in examining the relationship of HRM-OC relationship. However, the mixed method approach is unable to deal with scale development and to get better results from interviews. Therefore, there is substantial need to use mix-method for triangulation and a better understanding of empirical results. It will also help to draw more conclusive findings and in-depth analysis of the use of different methodologies. Therefore, there is also a need to perform analysis on multi-actor, and multi-level basis as there exist lot more differences at an individual and organizational level as well. As the commitment of employees is mostly time variant. So it is suggested to take responsibility at different times to fill this gap and also to overcome variance issue which cross-sectional research design is unable to predict.

The above mentioned methodological issues will help in understanding the real issue in HRM-OC research. Future scholars should consider these issues to have a better understanding of the relationship and also to draw insightful conclusions which could help managers and policymakers to develop healthy HR practices for their employees to gain favorable work outcomes.

\section{References}

Agarwala, T. (2003), "Innovative human resource practices and organizational commitment: an empirical investigation”, International Journal of Human Resource Management, Vol. 14 No. 2, pp. 175-97.

Arduini, D. and Zanfei, A. (2014), "An overview of scholarly research on public e-services? A metaanalysis of the literature", Telecommunications Policy, Vol. 38 Nos 5/6, pp. 476-95.

Arregle, J.L., Hébert, L. and Beamish, P.W. (2006), "Mode of international entry: the advantages of multilevel methods", Management International Review, Vol. 46 No. 5, pp. 597-618.

Arthur, J.B. and Boyles, T. (2007), "Validating the human resource system structure: a levelsbased strategic HRM approach", Human Resource Management Review, Vol. 17 No. 1, pp. 7792.

Blau, P.M. (1964), Exchange and Power in Social Life, John Wiley \& Sons, New York, NY. Boselie, P. (2010), "High-performance work practices in the health care sector: a Dutch case study", International Journal of Manpower, Vol. 31 No. 1, pp. 42-58.

Boselie, P., Dietz, G. and Boon, C. (2005), "Commonalities and contradictions in HRM and performance research", Human Resource Management Journal, Vol. 15 No. 3, pp. 67-94.

Bowen, D.E. and Ostroff, C. (2004), "Understanding HRM-firm performance linkages: the role of the 'strength' of the HRM system", Academy of Management Review, Vol. 29 No. 2, pp. 20321.

Boxall, P., Ang, S.H. and Bartram, T. (2011), “Analyzing the black box of HRM: uncovering HR goals, mediators, and outcomes in a standardized service environment", Journal of Management Studies, Vol. 48 No. 7, pp. 1504-32. 
INTERNATIONAL JOURNAL OF ACADEMIC RESEARCH IN BUSINESS AND SOCIAL SCIENCES Vol. 8, No. 11, Nov, 2018, E-ISSN: 2222-6990 @ 2018 HRMARS

Chang, E. (2005), "Employees overall perception of HRM effectiveness", Human Relations, Vol. 58 No. 4, pp. 523-44.

Chang, P.C. and Chen, S.J. (2011), "Crossing the level of employees performance: HPWS, affective commitment, human capital, and employee job performance in professional service organizations", The International Journal of Human Resource Management, Vol. 22 No. 4, pp. 883-901.

Cook, T.D., Campbell, D.T. and Day, A. (1979), Quasi-Experimentation: Design \& Analysis Issues for Field Settings, Houghton Mifflin Company, Boston, MA.

Gao-Urhahn, X., Biemann, T. and Jaros, S.J. (2016), "How affective commitment to the organization changes over time: a longitudinal analysis of the reciprocal relationships between affective organizational commitment and income", Journal of Organizational Behavior, Vol. 37 No. 4, pp. 515-36.

Gardner, T.M., Wright, P.M. and Moynihan, L.M. (2011), "The impact of motivation, empowerment, and skillenhancing practices on aggregate voluntary turnover: the mediating effect of collective affective commitment", Personnel Psychology, Vol. 64 No. 2, pp. 315-50.

Gerhart, B., Wright, P.M. and McMahan, G.C. (2000), "Measurement error in research on the human resources and firm performance relationship: further evidence and analysis", Personnel Psychology, Vol. 53 No. 4, pp. 855-72.

Gerhart, B., Wright, P.M., McMahan, G.C. and Snell, S.A. (2000), "Measurement error in research on human resources and firm performance: how much error is there and how does it influence effect size estimates?", Personnel Psychology, Vol. 53 No. 4, pp. 803-34.

Gibbs, T. and Ashill, N.J. (2013), "The effects of high-performance work practices on job outcomes: evidence from frontline employees in Russia", International Journal of Bank Marketing, Vol. 31 No. 4, pp. 305-26.

Gould-Williams, J. (2004), "The effects of high commitment HRM practices on employee attitude: the views of public sector workers", Public Administration, Vol. 82 No. 1, pp. 63-81.

Guest, D.E. (1999), "Human resource management - the workers' verdict", Human Resource Management Journal, Vol. 9 No. 3, pp. 5-25.

Guest, D.E. (2011), "Human resource management and performance: still searching for some answers", Human Resource Management Journal, Vol. 21 No. 1, pp. 3-13.

Hannah, D. and Iverson, R. (2004), "Employment relationships in context: implications for policy and practice", in Coyle-Shapiro, J., Shore, L., Taylor, S. and Tetrick, L. (Eds), The Employment Relationship: Examining Psychological and Contextual Perspectives, Oxford University Press, Oxford, pp. 332-50. INDUSTRIAL AND COMMERCIAL TRAINING Downloaded by GoetheUniversität Frankfurt At 01:39 20 October 2017 (PT) INDUSTRIAL AND COMMERCIAL TRAINING Hayton, J.C., Piperopoulos, P. and Welbourne, T.M. (2011), “Celebrating 50 years: 50 years of knowledge sharing: learning from a field moving forward", Human Resource Management, Vol. 50 No. 6, pp. 697-714.

Herrbach, O., Mignonac, K., Vandenberghe, C. and Negrini, A. (2009), "Perceived HRM practices, organizational commitment, and voluntary early retirement among late-career managers", Human Resource Management, Vol. 48 No. 6, pp. 895-915. 
INTERNATIONAL JOURNAL OF ACADEMIC RESEARCH IN BUSINESS AND SOCIAL SCIENCES Vol. 8, No. 11, Nov, 2018, E-ISSN: 2222-6990 @ 2018 HRMARS

Hitt, M.A., Beamish, P.W., Jackson, S.E. and Mathieu, J.E. (2007), "Building theoretical and empirical bridges across levels: multilevel research in management", Academy of Management Journal, Vol. 50 No. 6, pp. 1385-99.

Huselid, M.A. and Becker, B.E. (2000), "Comment on measurement error in research on human resources and firm performance: how much error is there and how does it influence effect size estimates?", Personnel Psychology, Vol. 53 No. 4, pp. 835-54.

Johnson, B. and Christensen, L. (2004), Educational Research: Quantitative, Qualitative, and Mixed Approaches, Pearson, Boston, MA.

Johnson, B. and Turner, L.A. (2003), "Data collection strategies in mixed methods research", in Tashakkori, A.and Teddlie, C. (Eds), Handbook of Mixed Methods in Social and Behavioural Research, Sage Publications, Thousand Oaks, CA, pp. 297-319.

Kinnie, N., Hutchinson, S., Purcell, J., Rayton, B. and Swart, J. (2005), "Satisfaction with HR practices and commitment to the organization: why one size does not fit all", Human Resource Management Journal, Vol. 15 No. 4, pp. 9-29.

Kooij, D.T., Jansen, P.G., Dikkers, J.S. and De Lange, A.H. (2010), "The influence of age on the associations between HR practices and both affective commitment and job satisfaction: a meta-analysis", Journal of Organizational Behavior, Vol. 31 No. 8, pp. 1111-36.

Lai, Y., Saridakis, G. and Johnstone, S. (2016), "Human resource practices, employee attitudes and small firm performance", International Small Business Journal, Vol. 35 No. 4, pp. 470-94.

Little, T.D., Card, N.A., Preacher, K.J. and McConnell, E. (2009), "Modeling longitudinal data from research on adolescence", in Lerner, R.M. and Steinberg, L. (Eds), Handbook of Adolescent Psychology, John Wiley \& Sons, New York, NY, pp. 15-52.

Messersmith, J.G., Patel, P.C., Lepak, D.P. and Gould-Williams, J.S. (2011), "Unlocking the black box: exploring the link between high-performance work systems and performance", Journal of Applied Psychology, Vol. 96 No. 6, pp. 1105-18.

Meyer, J.P. and Allen, N.J. (1997), Commitment in Workplace: Theory, Research and Application, Sage Publications, Thousand Oaks, CA.

Meyer, J.P. and Herscovitch, L. (2001), "Commitment in the workplace: toward a general model", Human Resource Management Review, Vol. 11 No. 3, pp. 299-326.

Meyer, J.P. and Smith, C.A. (2000), "HRM practices and organizational commitment: test of a mediation model", Canadian Journal of Administrative Sciences, Vol. 17 No. 4, pp. 319-31.

Meyer, J.P., Stanley, D.J., Herscovitch, L. and Topolnytsky, L. (2002), "Affective, continuance, and normative commitment to the organization: a meta-analysis of antecedents, correlates, and consequences", Journal of Vocational Behavior, Vol. 61 No. 1, pp. 20-52.

Mowday, R.T. (1983), "Beliefs about the causes of behavior: the motivational implications of attribution process", in Steers, R.M. and Porter, L.W. (Eds), Motivation \& Work Behavior, 3rd ed., McGraw-Hill, New York, NY, pp. 352-74.

Mowday, R.T., Steers, R.M. and Porter, L.W. (1979), "The measurement of organizational commitment", Journal of Vocational Behavior, Vol. 14 No. 2, pp. 224-47.

Ostroff, C. and Bowen, D.E. (2000), "Moving HR to a higher level: HR practices and organizational effectiveness", in Klein, K.L. and Kozlowski, S.W.J. (Eds), Multilevel Theory, Research, and 
Methods in Organizations: Foundations, Extensions, and New Directions, Jossey-Bass, San Francisco, CA, pp. 211-66.

Paauwe, J. (2009), "HRM and performance: achievements, methodological issues and prospects", Journal of Management Studies, Vol. 46 No. 1, pp. 129-42. Downloaded by Goethe-Universität Frankfurt At 01:39 20 October 2017 (PT)

Peterson, M.F., Arregle, J.L. and Martin, X. (2012), "Multilevel models in international business research", Journal of International Business Studies, Vol. 43 No. 5, pp. 451-7.

Podsakoff, P.M., MacKenzie, S.B., Lee, J.Y. and Podsakoff, N.P. (2003), "Common method biases in behavioral research: a critical review of the literature and recommended remedies", Journal of Applied Psychology, Vol. 88 No. 5, pp. 879-903.

Ramaprasad, B.S., Nandan Prabhu, K.P., Lakshminarayanan, S. and Pai, Y.P. (2017), "Human resource management practices and organizational commitment: a comprehensive review (2001-2016)", Prabandhan: Indian Journal of Management, Vol. 10 No. 10, pp. 7-23.

Riketta, M. (2002), "Attitudinal organizational commitment and job performance: a metaanalysis", Journal of Organizational Behavior, Vol. 23 No. 3, pp. 257-66.

Rousseau, D. (1995), Psychological Contracts in Organizations: Understanding Written and Unwritten Agreements, Sage Publications, Thousand Oaks, CA.

Rousseau, D.M. and Barends, E.G. (2011), "Becoming an evidence-based HR practitioner", Human Resource Management Journal, Vol. 21 No. 3, pp. 221-35.

Sanders, K. and Yang, H. (2016), "The HRM process approach: the influence of employees attribution to explain the HRM-performance relationship", Human Resource Management, Vol. 55 No. 2, pp. 201-17.

Sanders, K., Bainbridge, H.T.J., Kim, S., Cogin, J. and Lin, C.-H. (2012), "Strategic human resource management: a content analysis", paper presented at the 73rd annual meeting of the Academy of Management, Boston, MA, August.

Wall, T.D. and Wood, S.J. (2005), "The romance of human resource management and business performance, and the case for big science", Human Relations, Vol. 58 No. 4, pp. 429-62.

Wasti, S.A. (2003), "Organizational commitment, turnover intentions and the influence of cultural values", Journal of Occupational and Organizational Psychology, Vol. 76 No. 3, pp. 303-21.

Wright, P.M. and Boswell, W.R. (2002), "Desegregating HRM: a review and synthesis of micro and macro human resource management research", Journal of Management, Vol. 28 No. 3, pp. 247-76.

Wright, P.M., Gardner, T.M. and Moynihan, L.M. (2003), "The impact of HR practices on the performance of business units", Human Resource Management Journal, Vol. 13 No. 3, pp. 2136.

Young, S., Bartram, T., Stanton, P. and Leggat, S.G. (2010), “High-performance work systems and employee well-being: a two stage study of a rural Australian hospital", Journal of Health Organization and Management, Vol. 24 No. 2, pp. 182-99. 